\title{
PERSEPSI MAHASISWA PRODI SARJANA KESEHATAN MASYARAKAT STIKES DHARMA HUSADA BANDUNG TERHADAP PENERAPAN ADAPTASI KEBIASAAN BARU DI MASA PANDEMI COVID-19 TAHUN 2021
}

\author{
Gugum Pamungkas, Metha Dwitamara, Intan Puspita Sari \\ Prodi Sarjana Kesehatan Masyarakat, Sekolah Tinggi Ilmu Kesehatan Dharma Husada Bandung \\ gugumpamungkas@gmail.com, metha.stikesdhb@gmail.com,puspitaaaas@gmail.com
}

\begin{abstract}
ABSTRAK
Persepsi merupakan proses pemberian arti terhadap lingkungan atau objek oleh individu. Persepsi yang muncul dari dalam individu ini kemudian menggerakkan masing-masing individu untuk dapat mengatur dan mengelola dirinya dalam menerapkan protokol kesehatan sebagai kebiasaan baru yang diberlakukan di beberapa tatanan pada masa pandemi COVID19. Tujuan dari penelitian ini adalah untuk mengetahui persepsi mahasiswa kesehatan terhadap AKB pada masa pandemi COVID-19. Pada penelitian ini menggunakan pendekatan kualitatif dengan metode deskriptif. Sampel dalam penelitian ini adalah mahasiswa tingkat akhir non regular dan mahasiswa tingkat dua regular, jumlah keseluruhan sampel berjumlah 6 orang. Teknik pengumpulan data yang digunakan adalah wawancara, observasi dan dokumentasi kepada mahasiswa kesehatan. Hasil penelitian menunjukkan Pesepsi mahasiswa kesehatan terhadap penerapan AKB di kampus, terdapat mahasiswa yang berpersepsi bahwa protokol kesehatan yang sudah diberlakukan di kampus masih kurang efektif. Persepsi mahasiswa kesehatan terhadap penerapan $\mathrm{AKB}$ di tempat ibadah, hampir semua mahasiswa berpersepsi penerapan AKB di tempat ibadah sudah efektif. Persepsi mahasiswa kesehatan terhadap penerapan $\mathrm{AKB}$ di transportasi umum, hampir semua berpersepsi bahwa penerapan protokol kesehatan yang sudah di terapkan pada transportasi umum online seperti Gojek dan Grab sudah cukup baik. Persepsi mahasiswa kesehatan terhadap penerapan AKB di tempat umum, sebagian mahasiswa berpersepsi bahwa penerapan AKB tersebut masih kurang efektif dan kondusif. Persepsi mahasiswa kesehatan terhadap rencana tindak lanjut sebagai mahasiswa kesehatan dalam menghadapi AKB adalah dengan melakukan promosi kesehatan.
\end{abstract}

Kata kunci : Persepsi, Mahasiswa Kesehatan Masyarakat, Adaptasi Kebiasaan Baru, COVID19

\section{PENDAHULUAN}

Sejak Januari 2020, World Health Organization (WHO) telah menyatakan dunia masuk ke dalam darurat global terkait virus corona (COVID-19). Dimulai dari daerah Wuhan, Propinsi Hubei China, wabah ini menyebar luas ke seluruh Jurnal Penelitian Kesehatan STIKes Dharma Husada Bandung negara yang ada di dunia. Data WHO pada Mei 2020 tercatat negara yang terdampak telah mencapai 216 negara dengan jumlah pasien yang terkonfirmasi telah mencapai 5.596.550 dan angka kematian mencapai 353.373 jiwa. ${ }^{1}$ Kemudian, data WHO per

15 Juli 2021 menunjukkan negara yang 185 
terdampak telah mencapai 237 negara dengan jumlah yang terkonfirmasi mencapai 188.128.952 dan angka kematian mencapai 4.059.339. ${ }^{2}$ Kondisi di Indonesia sendiri per 15 Juli 2021 menepati peringkat pertama di dunia dengan jumlah kematian harian tertinggi yaitu sebanyak 982 dan jumlah total kematian 70.192, jumlah kasus terkonfirmasi sebanyak 2.762.803 dengan angka kesembuhan sebanyak 2.176.412. Sedangkan di Jawa Barat kasus yang terkonfirmasi yaitu sebanyak 488.686 dengan angka kesembuhan sebanyak 374.078 dan angka kematian mencapai 7.028. Kota Bandung menempati urutan ke $5 \mathrm{kab} /$ kota dengan total kasus konfirmasi tertinggi jumlah kasus yang terkonfirmasi yaitu sebanyak 29.992 dengan angka kesembuhan sebanyak 23.563 dan angka kematian mencapai 799. ${ }^{3}$ Angka-angka tersebut tentu bukan angka yang membanggakan karena angka tersebut berkaitan dengan nyawa manusia.

Perkembangan kasus COVID-19 di Indonesia diawali dengan pemerintah mengumumkan secara resmi pada tanggal 2 maret 2020. Dua warga Indonesia yang positif mengatakan bahwa melakukan kontak langsung dengan warga Negara Jepang yang sedang berkunjung ke Indonesia. Tanggal 11 maret 2020, untuk pertama kalinya terdapat kasus meninggal diakibatkan karena virus corona tersebut.
Pada tanggal 14 Maret 2020, jumlah pasien positif COVID-19 di Indonesia tercatat sebanyak 96 orang. Sehari berikutnya, Presiden dan seluruh anggota kabinet menjalani test, di hari dimana jumlah pasien positif corona di Indonesia telah bertambah menjadi 117 orang. Hingga akhirnya penyebaran virus corona di Indonesia ini tersebar di 34 provinsi. ${ }^{4}$ Namun sejak tanggal 27 Maret 2020, perkembangan kasus di DKI Jakarta meningkat drastis. Penambahan kasus baru sebesar 153 orang saat angka kasus positif di Indonesia melampaui titik 1000 kasus, 83 di antara kasus baru tersebut ditemukan di DKI Jakarta. ${ }^{5}$ Beberapa faktor yang mendorong meningkatnya kasus terkonfirmasi COVID-19 yaitu terdapatnya pengujian yang meluas di Jakarta, dengan pengujian yang relatif masif, beberapa kasus yang menunjukkan indikasi COVID19 terdata. Di Jawa Barat, kasus kumulatif juga meningkat drastis sekitar tanggal 25 Maret 2020. Hal ini pula diakibatkan karena pada periode tersebut pemerintahan Jawa Barat melalui Gubernur Ridwan Kamil melakukan langkah uji masif COVID-19. Perkembangan ini terjadi sekitar seminggu lebih setelah konfirmasi kasus pertama di Indonesia. Semua peningkatan kasus ini terjadi seiring dengan tersedianya perlengkapan penguji yang mulai didistribusikan secara luas ke 
beberapa wilayah. ${ }^{6}$ Hingga Presiden membuat suatu keputusan yaitu Keputusan Presiden Republik Indonesia nomor 12 tahun 2020 tentang penetapan bencana non alam penyebaran corona virus disease 2019 (COVID-19) sebagai bencana nasional tanggal 13 April 2020.

Meningkatnya penyebaran COVID-19 di Indonesia, pemerintah melalui Kementerian Kesehatan (KeMenKes) menerapkan kebijakan Pembatasan Sosial Berskala Besar (PSBB) melalui Permenkes 9 tahun 2020 mengenai Panduan PSBB dalam rangka percepatan penanganan COVID-19. Akan tetapi, pandemi COVID19 ini tidak hanya berdampak pada sektor kesehatan saja, namun juga sektor lainnya seperti pendidikan, ekonomi, pariwisata, dan sebagainya. Mempertimbangkan kerugian lain dari penerapan stay at home yang kemudian disusul dengan pemberlakuan kebijakan study at home dan work from home yang membuat berkurangnya produktivitas masyarakat menyebabkan perekonomian menjadi tidak stabil, sehingga Indonesia mulai mengadopsi new normal pada pertengahan Juni $2020^{7}$.

Diawali dengan pernyataan Presiden Jokowi untuk mempersiapkan diri hidup berdampingan dengan COVID-19. Sebagaimana halnya gagasan New Normal yang dikeluarkan oleh WHO pada akhir
April 2020. New Normal merupakan mekanisme transisi untuk mendorong kembali bergulirnya aktivitas masyarakat. Pernyataan Presiden tersebut juga diikuti dengan penyiapan berbagai protokol aman dari COVID-19 yang diperlukan di tempat kerja, lembaga pelayanan publik, institusi pendidikan, institusi agama, lalu lintas dan sebagainya. ${ }^{8} \quad$ Namun, dalam perkembangannya istilah new normal dianggap menimbulkan kebingungan di masyarakat. Maka pemerintah melakukan revisi pedoman pencegahan COVID-19 di Indonesia, dengan penggantian new normal menjadi Adaptasi Kebiasaan Baru (AKB). Walaupun secara makna memiliki perbedaan, namun subtansinya sama yaitu adaptasi berbagai protokol kesehatan di berbagai tempat seperti di rumah, di transportasi umum, di sekolah, di tempat kerja, di tempat ibadah dan di tempat umum seperti terminal,pasar dan mall dengan menerapkan perilaku hidup bersih dan sehat untuk selalu mencuci tangan menggunakan sabun dan air bersih, melakukan social distancing atau physical distancing dengan menjaga jarak minimal satu meter dengan orang lain, menghindari kerumunan dan membatasi mobilisasi. ${ }^{9}$

Setelah pemberlakuan protokol kesehatan sebagai adaptasi kebiasaan baru tersebut, pemerintah mengumumkan dalam satu harinya terdapat lebih dari 1.000 kasus 
baru terkonfirmasi COVID-19 yang sebelumnya jumlah kasus harian ada di rentang 600-700 kasus. Hingga saat ini jumlah kenaikan kasus di Indonesia telah mencapai 56.757 dan di Kota Bandung sebanyak 4.397. ${ }^{3}$ Peneliti dari Pemprov DIY, mengungkapkan faktor yang membuat kurva semakin meningkat adalah masyarakat yang kembali melakukan aktivitasnya secara normal tetapi tidak menerapkan protokol kesehatan sebagai kebiasaan baru mereka seperti tidak menggunakan masker pada saat keluar rumah, tidak rutin mencuci tangan dengan sabun dan air bersih sebelum dan sesudah melakukan aktivitas dan tidak menjaga jarak saat berada di tempat umum, sehingga dapat menyebabkan meningkatkannya risiko masyarakat untuk terpapar COVID-19 tersebut $^{10}$. Oleh karena itu, kebijakan pemerintah mengenai adaptasi kebiasaan baru, harus diikuti dengan adanya sosialisasi berkelanjutan kepada masyarakat karena penularan COVID-19 dapat dicegah dengan pengetahuan dan sikap yang baik terhadap masyarakat salah satunya adalah mahasiswa kesehatan.

Mahasiswa kesehatan selaku garda terdepan dalam fasilitas pelayanan kesehatan kedepannya, turut berpartisipasi aktif dalam mengikuti trend issue permasalahan kesehatan yang sedang Jurnal Penelitian Kesehatan STIKes Dharma Husada Bandung terjadi. Mahasiswa kesehatan sebagai diri pribadi dengan kehidupan yang mereka jalani mempunyai dampak resiko kesehatan yang besar, sehingga menjadi penting bagi mereka untuk meningkatkan kesadaran diri akan pentingnya informasi kesehatan bagi dirinya. Isu-isu kesehatan, masalah-masalah kesehatan serta pemecahan kesehatan yang terbaik bagi mereka perlu dipahami dan dipergunakan sebagai informasi kesehatan untuk meningkatkan serta mempertahankan kesehatan mereka ${ }^{11}$.

Sosialisasi berkelanjutan mengenai protokol kesehatan tersebut sebagai kebiasaan baru menjadi penting karena diperkuat dengan fakta bahwa di Indonesia penularan COVID-19 merupakan kategori community transmission. ${ }^{12}$ Kategori ini menandakan bahwa peningkatan kasus yang terjadi setiap harinya karena adanya risiko penularan cukup tinggi antara satu orang dengan orang lainnya dalam komunitas atau masyarakat. ${ }^{7}$ Akan tetapi, peningkatan perilaku masyarakat sendiri dalam menerapkan protokol kesehatan sebagai adaptasi kebiasaan baru demi menurunnya kasus COVID-19 sangatlah dipengaruhi oleh persepsi masing-masing individu.

Berdasarkan teori yang dikemukan oleh Gibson, Ivancevich dan Donnelly persepsi merupakan proses pemberian arti 
terhadap lingkungan atau objek oleh individu. Persepsi tersebut dapat dipengaruhi oleh dua faktor yaitu faktor internal seperti perhatian, minat, kebutuhan yang searah, pengalaman dan suasana hati. Dan faktor eksternal seperti karakteristik lingkungan dan objek yang terlibat di dalamnya. ${ }^{13}$ Persepsi yang muncul dari dalam individu ini kemudian menggerakkan masing-masing individu untuk dapat mengatur dan mengelola dirinya dalam menerapkan protokol kesehatan sebagai kebiasaan baru yang diberlakukan di beberapa tempat seperti di institusi pendidikan (perguruan tinggi), di tempat ibadah, di tempat umum, dan di transportasi umum pada masa pandemi COVID-19 saat ini.

Berdasarkan hasil wawancara dengan beberapa mahasiswa prodi sarjana kesehatan masyarakat yang sudah mulai menerapkan protokol kesehatan sebagai kebiasaan baru di beberapa tatanan pada masa pandemi COVID-19 ini didapatkan informasi, bahwa terdapat mahasiswa yang berpersepsi penerapan protokol kesehatan sebagai kebiasaan baru di kampus sudah diterapkan dengan cukup baik dimana sudah terdapat sarana tempat cuci tangan, handsinitizer, pengukuran suhu tubuh sebelum memasuki lingkungan kampus dan membatasi kegiatan pembelajaran dengan melaksanakan pembelajaran secara Jurnal Penelitian Kesehatan STIKes Dharma Husada Bandung

daring sehingga pembelajaran dapat dilakukan dimana saja, namun terdapat mahasiswa yang berpersepsi penerapan protokol kesehatan di kampus masih kurang efektif karena pengecekkan suhu sebelum memasuki kampus sudah tidak diterapkan dan dengan masih harus melakukan pembelajaran secara daring atau online membuat kurangnya pemahaman terhadap materi perkuliahan dan membuat kurangnya sosialisasi dengan teman secara langsung. Untuk penerapan adaptasi kebiasaan baru di rumah ibadah, terdapat mahasiswa yang berpersepsi bahwa masih kurangnya kedisiplinan pengurus ataupun masyarakat yang melaksanakan ibadah dalam penerapan protokol kesehatan dimana pada saat pelaksanaan shalat tidak berjarak antara satu dengan yang lainnya dan tidak disediakan handsinitizer di rumah ibadah tersebut, tetapi terdapat juga mahasiswa yang berpersepsi bahwa penerapan protokol kesehatan di tempat ibadah sudah baik dimana tersedia handsanitizer, shalat dilaksanakan menjaga jarak dan diberi tanda serta disediakan juga masker untuk jamaah yang tidak menggunakan masker saat akan beribadah.

Untuk penerapan adaptasi kebiasaan baru di transportasi umum, terdapat mahasiswa yang berpersepsi bahwa belum semua transportasi umum menerapkan 
JURNAL SEHAT MASADA VOLUME XVI

protokol kesehatn seperti di angkutan kota (angkot) tidak disedikan handsinitizer dan antar penumpang tidak berjarak. Kemudian, terdapat mahasiswa yang berpersepsi bahwa sudah banyak transportasi umum yang menerapkan protokol kesehatan seperti transportasi umum yang dapat di pesan secara online yaitu gojek,grab dimana pengemudi sudah di cek terlebih dahulu suhu tubuhnya sebelum mengantar/menjemput penumpang, menggunakan masker, menyediakan handsanitizer dan memasang pembatas antara pengemudi dan penumpang. Untuk penerapan adaptasi kebiasaan baru di tempat umum seperti di pasar/supermarket/tempat makan, mahasiswa berpersepsi bahwa penerapan protokol kesehatan sudah baik dimana sebelum masuk disediakan handsanitizer, di cek suhu tubuh dan diatur/dibatasi jumlah orang yang diperbolehkan masuk. Tetapi juga terdapat mahasiswa yang berpersepsi bahwa penerapan protokol kesehatan masih belum diterapkan dengan pedagang banyak yang tidak menggunakan masker dan masih terdapat kerumunan pada saat melakukan jual beli dan di supermarket pada saat mengantri untuk membayar tidak berjarak atau tidak berdiri sesuai tanda jaga jarak yang sudah dibuat. baik untuk di pasar/supermarket dimana

Dari hasil wawancara tersebut dapat diketahui bahwa, penerapan protokol kesehatan sebagai adaptasi kebiasaan baru yang diberlakukan di beberpa tatanan pada masa pandemi COVID-19 ini menimbulkan persepsi yang berbeda-beda diantara masing-masing mahasiswa kesehatan. Maka berdasarkan penjabaran latar belakang masalah tersebut, penulis tertarik untuk melakukan penelitian dengan judul "Persepsi Mahasiswa Prodi Sarjana Kesehatan Masyarakat STIKes Dharma Husada Bandung Terhadap Penerapan Adaptasi Kebiasaan Baru di Masa Pandemi COVID-19 Tahun 2021".

\section{METODE PENELITIAN}

Penelitian ini menggunakan penelitian pendekatan kualitatif dengan metode deskriptif, penelitian kualitatif yaitu suatu penelitian yang digunakan untuk memahami fenomena apa yang dialami oleh subjek penelitian dengan cara mendeskripsikan dalam bentuk kata-kata dan bahasa pada suatu konteks khusus yang alamiah dan dengan memanfaatkan berbagai metode alamiah ${ }^{29}$.

Metode penelitian deskriptif merupakan metode penelitian yang menggambarkan dan menginterpretasikan obyek sesuai dengan apa adanya. ${ }^{30}$ Bersifat deskriptif karena penelitian ini bertujuan untuk memperoleh gambaran tentang 
persepsi mahasiswa Prodi Sarjana

Kesehatan Masyarakat STIKes Dharma Husada Bandung terhadap penerapan Adaptasi Kebiasaan Baru di masa pandemi COVID-19 tahun 2021.

Subjek dalam penelitian ini dapat disebut sebagai informan, informan adalah orang yang akan memberikan informasi mengenai pertanyaan penelitian. Pemilihan informan pada penelitian ini dilakukan dengan menggunakan teknik purposive sampling yaitu teknik pengambilan sampel berdasarkan atas kriteria dengan berpedoman pada kesesuaian dan kecukupan menurut peneliti.

Informan dalam penelitian ini terbagi dua, yaitu Key Informan atau informan kunci yang merupakan mahasiswa prodi sarjana kesehatan masyarakat tingkat akhir non regular dan Secondary Informan atau informan pendukung dalam penelitian ini yaitu mahasiswa prodi kesehatan masyarakat tingkat dua regular. Adapun kriteria inklusi dan eksklusi yaitu sebagai berikut :

a. Kriteria Inklusi :

1) Mahasiswa prodi sarjana kesehatan masyarakat yang masih aktif dan memiliki mobilitas tinggi

2) Mahasiswa kesehatan yang bersedia menjadi responden

b. Kriteria Eksklusi :
Mahasiswa kesehatan yang tidak bersedia menjadi responden atau yang tidak hadir dalam proses pengumpulan data.

\section{HASIL DAN PEMBAHASAN}

a. Adaptasi Kebiasaan Baru

Hasil penelitian menunjukkan bahwa hampir semua informan mengungkapkan bahwa tujuan dari pemberlakuan Adaptasi Kebiasaan Baru tersebut adalah untuk mencegah dan meminimalisir penyebaran COVID-19 agar tidak semakin meningkat, selain itu juga tujuan diberlakukannya Adaptasi Kebiasaan Baru adalah sebagai upaya memulihkan kembali dan mendukung keberlangsungan ekonomi serta aktivitas sektor-sektor yang sempat tersendat oleh penyebaran virus ini, namun dengan cara beriringan dengan upaya pencegahan atau pengendalian penularan virus COVID-19. Semua informan pun berpendapat penerapan Adaptasi Kebiasaan Baru merupakan hal yang penting dan wajib diterapkan oleh semua masyarakat, walaupun pada awal penerapannya mereka merasa tidak nyaman untuk membiasakan menerapkan protokol kesehatan sebagai Adaptasi Kebiasaan Baru, karena hal yang biasanya tidak 
dilakukan seperti memakai masker saat keluar rumah atau pada saat berinteraksi dengan orang lain, membawa hand sanitizer, sering mencuci tangan, menjaga jarak dan membatasi mobilitas harus dilakukan selama masa pandemi COVID-19 ini, mengingat keberhasilan kebijakan Adaptasi Kebiasaan Baru akan sangat ditentukan oleh ketaatan masyarakat dalam melaksanakan kebijakan tersebut.

\section{b. Persepsi Mahasiswa Prodi Sarjana} Kesehatan Masyarakat Terhadap Penerapan Adaptasi Kebiasaan Baru di Institusi Pendidikan (Perguruan Tinggi)

Hasil penelitian menunjukkan bahwa penerapan protokol kesehatan di kampus masih belum dapat dilaksanakan dengan efektif salah satunya yaitu menjaga jarak, sejalan dengan hasil penelitian yang dilakukan oleh Arina, dkk menunjukkan bahwa hanya 4,2\% mahasiswa yang patuh dalam menjaga jarak. ${ }^{35}$ Peneliti pun berpandangan bahwa tidak hanya jaga jarak saja yang belum diterapkan secara efektif, pengecekkan suhu sebelum memasuki kampus pun tidak diterapkan dengan baik dan juga masih terdapat orang-orang disekitar kampus yang tidak menggunakan masker. Jurnal Penelitian Kesehatan STIKes Dharma Husada Bandung
Sehingga untuk dapat melaksanakan pengadaan pembelajaran tatap muka kembali kampus perlu mempersiapkan penerapan protokol kesehatan yang benar-benar dapat dilaksanakan secara efektif oleh seluruh warga kampus. Akan tetapi dari hasil observasi penelitian dilapangan yang telah dilakukan menunjukkan bahwa semua informan dapat menjaga jarak dengan orang sekitar dan semua informan menerapkan protokol kesehatan lainnya seperti menggunakan masker, mencuci tangan dengan baik dan benar dan selalu membawa handsanitizer. Namun dengan mengetahui bahwa masih terdapat protokol kesehatan yang belum dilakukan secara maksimal, maka untuk mempersiapkan pengadaan pembelajaran secara tatap muka kembali, perlu di terapkan protokol kesehatan yang benar-benar ketat sesuai dengan panduan pembelajaran semester genap TA 2020/2021 di masa pandemi COVID19.

c. Persepsi Mahasiswa Prodi Sarjana Kesehatan Masyarakat Terhadap Penerapan Adaptasi Kebiasaan Baru di Tempat Ibadah 
Dari hasil penelitian menunjukkan terdapat informan berpersepsi bahwa sebagian tempat ibadah sudah menerapkan protokol kesehatan sebagai Adaptasi Kebiasaan Baru dengan baik, peneliti pun berpandangan bahwa beberapa masjid sudah menerapkan protokol kesehatan dengan baik, seperti membatasi jamaah yang dapat beribadah hanya $50 \%$, menerapkan jaga jarak saat beribadah, jamaah menggunakan masker, membawa alat shalat pribadi dan sebelum memasukki masjid terdapat pengecekkan suhu serta mencuci tangan menggunakan sabun dan air bersih. Persepsi positif dari beberapa informan juga dipengaruhi dengan melihat lingkungan sekitarnya yang sudah menerapkan protokol kesehatan dengan baik saat melaksanakan ibadah di tempat ibadah. Seperti yang diungkapkan oleh,

"sudah menerapkan protokol kesehatan seperti memakai masker dan mencuci tangan” $\left(I^{4}\right)$

“Untuk lingkungan sekitar, semuanya menerapkan” $\left(I^{5}\right)$

"masyarakatnya semua pada mematuhi” $\left(I^{6}\right)$

Namun terdapat juga beberapa informan yang mengungkapkan bahwa lingkungan disekitarnya masih belum dapat menerapkan protokol kesehatan yang diterapkan di tempat ibadah dengan baik, seperti yang diungkapkan informan berikut,

"Untuk di lingkungan sekitar dalam menerapkan $A K B$ sejauh ini ada yang menerapkan dan ada yang tidak" $\left(I^{I}\right)$

“masih banyak yang tidak pakai masker, karna ngerasanya kalau ibadah itu harus melepas masker.” $\left(I^{2}\right)$

"Untuk lingkungan sekitar ada yang menerapkan ada yang tidak, karna merasa dirinya aman karna dekat rumah" $\left(I^{3}\right)$

Dengan keadaan lingkungan yang berbeda-beda dalam menerapkan protokol kesehatan di tempat ibadah membuat persepsi terhadap penerapan Adaptasi Kebiasaan Baru di tempat ibadah pun menjadi berbeda seperti yang di ungkapkan oleh informan $\mathrm{I}^{1}$, "Persepsinya untuk di tempat ibadah sebenernya agak kurang kondusif, misalkan ke tempat pembelanjaan ada mushola pun masih terjadi kerumunan, masih ada yang sering kontak fisik/tidak menggunakan masker pada saat antri untuk shalat" $\left(I^{l}\right)$

Dari hasil penelitian tersebut menunjukkan bahwa dengan melihat atau memperhatikan lingkungan sekitar dapat mempengaruhi persepsi mereka terhadap penerapan Adaptasi Kebiasaan Baru yang diberlakukan di tempat ibadah tersebut seperti dalam teori Gibson,dkk yang mengungkapkan bahwa persepsi seseorang dapat dipengaruhi oleh faktor internal 
(perhatian) dan faktor eksternal (lingkungan), namun dengan memiliki persepsi yang berbeda-beda tidak membuat mereka menjadi tidak menerapkan protokol kesehatan dengan baik pada saat melaksanakan ibadah di tempat ibadah. Karena mereka selaku mahasiswa kesehatan juga memiliki kesadaran lebih untuk terus patuh akan protokol kesehatan yang diberlakukan, hal ini sesuai dengan hasil observasi penelitian yang telah dilakukan menunjukkan semua informan mematuhi protokol dengan membawa alat shalat pribadi, memakai masker, selalu membawa hand sanitizer / mencuci tanggan dengan baik dan benar serta menjaga jarak dengan persentase mencapai $100 \%$.

d. Persepsi Mahasiswa Prodi Sarjana Kesehatan Masyarakat Terhadap Penerapan Adaptasi Kebiasaan Baru di Transportasi Umum

Hasil penelitian menunjukkan bahwa persepsi informan terhadap penerapan Adaptasi Kebiasaan Baru di transportasi umum online seperti GoJek dan Grab sudah cukup baik dengan pengemudi yang selalu memakai masker dan terdapat pembatas antara pengemudi dengan penumpang pada kendaraannya, sejalan dengan hasil penelitian yang dilakukan oleh Alfonsius yang menunjukkan bahwa GoJek menerapkan prosedur Jurnal Penelitian Kesehatan STIKes Dharma Husada Bandung kesehatan dan kebersihan sesuai dengan himbauan pemerintah pada era new normal. Pertama, pengemudi diwajibkan memakai masker dan sarung tangan yang merupakan ketentuan dalam menerima order dan penumpang juga diwajibkan memakai masker. Kedua, menjaga kebersihan serta kesehatan mitra maupun penumpang serta menyediakan sekat pelindung supaya penumpang merasakan keamanan ketika menggunakan ojek online. ${ }^{36}$ Peneliti pun berpandangan sama dengan informan bahwa penerapan protokol kesehatan di transportasi umum online sudah cukup baik jika di bandingkan dengan transportasi umum lainnya seperti angkot atau bis, karena pada transportasi online Gojek dan Grab sebelum driver atau pengemudi bekerja sudah dipastikan dalam kondisi sehat, memakai masker, terdapat pembatas antar pengemudi dan penumpang, serta menyediakan handsanitizer. Protokol kesehatan yang sudah diterapkan tersebut sesuai yang tertuang dalam Keputusan Menteri Kesehatan RI Nomor HK.01.07/MENKES/382/2020.

e. Persepsi Mahasiswa Prodi Sarjana Kesehatan Masyarakat Terhadap Penerapan Adaptasi Kebiasaan Baru di Tempat Umum 
Hasil penelitian menunjukkan bahwa sebagian besar informan telah menerapkan protokol kesehatan seperti memakai masker, mencuci tangan sebelum masuk dan melakukan pengecekkan suhu. Hal tersebut sesuai dengan hasil observasi penelitian yang telah dilakukan menunjukkan bahwa informan mencuci dengan baik dan benar, menggunakan masker dan selalu membawa handsanitizer sudah mencapai $100 \%$ yang artinya semua informan telah menerapkan protokol tersebut. Selanjutnya, hasil observasi penelitian menunjukkan bahwa 50\% informan selalu membawa membawa alat makan pribadi dan sebanyak $83,3 \%$ informan selalu membawa tempat minum/tumblr pribadi. Serta hasil observasi penelitian juga menunjukkan $\quad 66,7 \%$ informan memiliki alat pembayaran cashless dan cukup sering menggunakannya pada saat melakukan transaksi untuk menghindari terpaparnya virus COVID-19 melalui uang tunai. Kemudian dari hasil wawancara beberapa informan berpersepsi bahwa penerapan Adaptasi Kebiasaan Baru di tempat umum terbilang masih kurang kondusif/efektif seperti yang diungkapkan oleh beberapa informan sebagai berikut, "kalau di tempat umum kurang kondusif, ambil

contohnya mall awal-awal iya mereka sangat aware banget untuk penerapannya tapi makin ke sini yang diliat dan dialami pun kaya kurang kondusif penerapannya jadi kaya pengecekkan suhu tadi untuk formalitas dan masih ada kegiatankegiatan yang memicu kerumunan di dalam tempat umum sendiri seperti bazar” $\left(I^{1}\right)$

"Persepsinya kurang efektif, sekarang orang-orang menerapkan protokol kesehatan tapi hanya sekedar menerapkan kaya maskernya tapi masih banyak restoran/mall juga tidak membatasi jumlah pengunjungnya" $\left(I^{4}\right)$

“Kalau di pasar bener-bener belum efektif orang-orang seperti tidak peduli dengan COVID dan seperti kurang edukasi mengenai penerapan protokol kesehatan" $\left(I^{5}\right)$

Pernyataan di atas menunjukkan bahwa informan berpersepsi terhadap penerapan Adaptasi Kebiasaan Baru di tempat umum masih kurang kondusif dimana protokol kesehatan yang diterapkan tidak sesuai dengan yang sudah tertuang dalam Keputusan Menteri Kesehatan Republik Indonesia Nomor HK.01.07/MENKES/382/2020. 


\section{f. Persepsi Mahasiswa Prodi Sarjana} Kesehatan Masyarakat Terhadap Rencana Tindak Lanjut Sebagai Mahasiswa Kesehatan dalam Menghadapi Adaptasi Kebiasaan Baru

Hasil penelitian menunjukkan bahwa informan berpersepsi terhadap rencana tindak lanjut sebagai mahasiswa kesehatan yaitu dengan melakukan promosi kesehatan dimulai dari lingkungan terdekat mereka terlebih dahulu dengan melakukan penyuluhan, melakukan himbauan dan juga mencontohkan penerapan protokol kesehatan secara langsung. Peneliti juga berpandangan dengan terus melakukan promosi kesehatan dengan memberikan edukasi melalui social media ataupun secara langsung mengenai pentingnya penerapan protokol kesehatan akan meningkatkan perilaku masyarakat dalam menerapkan adaptasi kebiasaan baru di masa pandemi COVID-19 menjadi lebih baik.

\section{g. Pandemi COVID-19}

Hasil penelitian menujukkan bahwa sebagian informan berpendapat COVID-19 merupakan virus yang menyerang saluran pernafasan yang dapat ditularkan melalui droplet dengan mekanisme batuk dan bersin serta melalui kontak fisik secara langsung dengan penderita COVID-19. Hasil penelitian pun menunjukkan, bahwa sebagian informan memperoleh informasi terkini terkait COVID-19 dari media sosial instagram/youtube. Adapun informan yang memperoleh informasi melalui aplikasi khusus dan juga dari berita. Menurut pandangan peneliti pun, social media lebih mudah diakses dan lebih cepat dalam mengupdate informasi terkini terkait COVID-19. Namun, terdapat pula informan yang kurang mencari tau informasi terkini mengenai COVID-19. Hal tersebut sesuai dengan hasil observasi penelitian bahwa yang menujukkan sumber informasi yang biasa diakses tentang COVID-19 hanya sebanyak 83,3\%, dimana masih terdapat informan yang kurang memperhatikan perkembangan dari permasalahan kesehatan yang sedang terjadi yaitu pandemi COVID-19.

\section{KESIMPULAN DAN SARAN}

a. Kesimpulan

Berdasarkan hasil penelitian mengenai Persepsi Mahasiswa Prodi 
Sarjana Kesehatan Masyarakat STIKes

Dharma Husada Bandung Terhadap Penerapan Adaptasi Kebiasaan Baru di Masa Pandemi COVID-19 dapat ditarik kesimpulan yakni :

1. Pesepsi mahasiswa Prodi Sarjana Kesehatan Masyarakat terhadap penerapan Adaptasi Kebiasaan Baru di perguruan tinggi/kampus, terdapat mahasiswa yang berpersepsi bahwa protokol kesehatan yang sudah diberlakukan di kampus masih kurang efektif karena semakin lama protokol kesehatan tidak diterapkan lagi secara ketat. Peneliti pun berpandangan bahwa belum semua protokol kesehatan di kampus diterapkan dengan baik.

2. Persepsi mahasiswa Prodi Sarjana Kesehatan Masyarakat terhadap penerapan Adaptasi kebiasaan Baru di tempat ibadah, hampir semua mahasiswa berpersepsi penerapan Adaptasi Kebiasaan Baru di tempat ibadah sudah efektif. Peneliti pun berpandangan bahwa beberapa masjid sudah menerapkan protokol kesehatan dengan baik. Sesuai dengan hasil observasi penelitian menunjukkan sebanyak 100\% informan menerapkan protokol kesehatan dengan memakai masker, mencuci tangan dengan baik dan benar, selalu membawa handsanitizer, menjaga jarak dan membawa alat shalat pribadi.

3. Persepsi mahasiswa Prodi Sarjana Kesehatan Masyarakat terhadap penerapan Adaptasi Kebiasaan Baru di transportasi umum, hampir semua berpersepsi bahwa penerapan protokol kesehatan yang sudah di terapkan pada transportasi umum online seperti gojek dan grab sudah cukup baik, peneliti pun memiliki pandangan yang sama dengan informan. Dimana dari hasil observasi penelitian menunjukkan bahwa sebanyak $100 \%$ informan telah menerapkan protokol kesehatan dengan menggunakan masker, selalu membawa handsanitizer dan menjaga jarak.

4. Persepsi mahasiswa Prodi Sarjana Kesehatan Masyarakat terhadap penerapan Adaptasi Kebiasaan Baru di tempat umum, sebagian mahasiswa berpersepsi bahwa penerapan Adaptasi Kebiasaan Baru tersebut masih kurang efektif dan kondusif. Peneliti juga berpandangan bahwa penerapan protokol kesehatan di tempat umum seperti di mall atau tempat 
makan kurang efektif. Berdasarkan hasil observasi penelitian pun menunjukkan sebanyak $100 \%$ informan menerapkan mencuci tangan dengan baik dan benar, menggunakan masker dan selalu membawa handsanitizer, $50 \%$ informan selalu membawa membawa alat makan pribadi dan $83,3 \%$ informan selalu membawa tempat minum/tumblr pribadi. Serta sebanyak $50 \%$ informan memiliki alat pembayaran cashless untuk melakukan transaksi.

5. Persepsi mahasiswa Prodi Sarjana Kesehatan Masyarakat terhadap rencana tindak lanjut sebagai mahasiswa kesehatan dalam menghadapi Adaptasi Kebiasaan Baru adalah dengan melakukan promosi kesehatan. Peneliti pun berpandangan dengan terus melakukan promosi kesehatan akan meningkatkan perilaku masyarakat dalam menerapkan adaptasi kebiasaan baru di masa pandemi COVID-19 menjadi lebih baik.

\section{b. Saran}

Berdasarkan hasil pembahasan dan kesimpulan penelitian maka disarankan : 1. Bagi Mahasiswa Kesehatan
Mahasiswa kesehatan dapat lebih aktif dalam membuat konten mengenai penerapan protokol kesehatan sebagai Adaptasi Kebiasaan Baru di masa pandemi COVID-19 di media sosial, mahasiswa dapat lebih aktif dalam mengedukasi dan melakukan promosi kesehatan mengenai protokol kesehatan yang harus diterapkan, serta mahasiswa dapat berpartisipasi aktif dengan satgas COVID-19 dan kritis dalam menyuarakan pentingnya menerapkan protokol kesehatan di masa pandemi COVID-19.

2. Bagi STIKes Dharma Husada Bandung

Dapat menjalin kemitraan dengan satgas wilayah agar mengetahui penerapan protokol kesehatan yang baik dan sesuai dengan ketentuan yang berlaku pada tatanan institusi pendidikan untuk mempersiapkan pengadaan pembelajaran secara tatap muka kembali. Serta menyediakan sarana dan pra sarana yang memadai yang dapat menunjang penerapan protokol kesehatan secara baik dan maksimal seperti adanya pengecekkan suhu kembali sebelum memasuki lingkungan 
kampus, penyediaan handsanitizer dan tempat cuci tangan di dalam lingkungan kampus, menyediakan masker gratis untuk warga kampus yang tidak menggunakan masker, penambahan ruang kelas dan penyediaan cairan disinfektan untuk mensterilkan ruangan kelas yang sudah digunakan.

3. Bagi Peneliti Selanjutnya

Bagi peneliti selanjutnya yang akan melakukan penelitian yang sama mengenai persepsi terhadap penerapan Adaptasi Kebiasaan Baru di masa pandemi COVID-19 dapat melakukan penelitian kepada stake holder/pemegang kebijakan di beberapa tatanan tersebut.

\section{DAFTAR PUSTAKA}

1. Zeegen EN, Yates AJ, Jevsevar DS. After the COVID-19 Pandemic: Returning to Normalcy or Returning to a New Normal? J Arthroplasty [Internet]. 2020;35(7):S37-41. Available from: https://doi.org/10.1016/j.arth.2020.04.040

2. World Health Organization. WHO Corona Virus (COVID-19) [Internet]. WHO. 2021. Available from: https://covid19.who.int/

3. Dr.Yori. Materi Webinar Prof.

4. Sukur moch halim. Penanganan Pelayanan Kesehatan Di Masa Pandemi Covid-19 Dalam Perspektif Hukum Kesehatan. J Inicio Legis Vol 1 Nomor 1 Oktober 2020. 2020;1:1-17.
5. Bayu DJ. Jumlah Kasus Positif Corona di Indonesia Tembus 1.000 Orang [Internet]. katadata.co.id. 2020. Available from:

https://katadata.co.id/agustiyanti/berita/5e9 a41f86665c/jumlah-kasus-positif-coronadi-indonesia-tembus-1000-orang

6. Vermonte P, Wicaksono TY. Karakteristik dan Persebaran COVID-19 di Indonesia: Temuan Awal. CSIS Comment. 2020;(April):1-12.

7. Masyarakat JL, Service P. SOSIALISASI MENUJU PENERAPAN ADAPTASI KEBIASAAN BARU PADA SANTRI PONDOK PESANTREN DI KABUPATEN LUMAJANG. 2020;4(2):29.

8. Wawan M, Poppy SW. New Normal Perubahan Sosial Ekonomi dan Politik Akibat Covid-19. jogjakarta: Gadjah Mada University Press; 2020.

9. Kemenkes. KEPUTUSAN MENTERI KESEHATAN REPUBLIK INDONESIA NOMOR HK.01.07/MENKES/382/2020 TENTANG PROTOKOL KESEHATAN BAGI MASYARAKAT DI TEMPAT DAN FASILITAS UMUM DALAM RANGKA PENCEGAHAN DAN PENGENDALIAN CORONA VIRUS DISEASE 2019 (COVID-19). 2020;40(2):119-29.

10. Azanella LA. Apakah Kasus Virus Corona di Indonesia Mulai Menurun? Berikut Hasil Hitungan Peneliti [Internet]. Kompas.com. 2020. Available from: https://www.kompas.com/tren/read/2020/0 6/13/132948665/apakah-kasus-viruscorona-di-indonesia-mulai-menurunberikut-hasil-hitungan?page $=$ all

11. Sukesih S, Usman U, Budi S, Sari DNA. Pengetahuan Dan Sikap Mahasiswa Kesehatan Tentang Pencegahan Covid-19 Di Indonesia. J Ilmu Keperawatan dan Kebidanan. 2020;11(2):258.

12. WHO. WHO Coronavirus Disease 
(COVID-19). In 2020.

13. Gibson, Ivancevich D. Organisasi, Perilaku, Struktur, Proses. Jilid 1. Jakarta: Binarupa Aksara; 1997.

14. Firma TB. NORMAL BARU DALAM PRAKTIK KEAGAMAAN ISLAM.

15. Karasmanaki E, Tsantopoulos G. Impacts of social distancing during COVID-19 pandemic on the daily life of forestry students. Child Youth Serv Rev [Internet]. 2021;120(September 2020):105781. Available from: https://doi.org/10.1016/j.childyouth.2020.1 05781

16. Churniawan E, Rozaq F, Perkeretaapian MT, Perkeretaapian P, Madiun I, Normal N, et al. Analisis Respon Penumpang Terhadap Penerapan New. 2021;V.

17. A. M. AAGTHI, Utami IGAC, Utami NWA. Penerapan Konsep "New Normal" Pada Desain Sirkulasi Dan Signage Pusat Perbelanjaan Di Kawasan Kuta, Bali. (Studi Kasus: Beachwalk Shopping Center). J Arsit Zo. 2020;3(3):256-64.

18. Persepsi G, Tentang M, Di PC-. Gambaran Persepsi Masyarakat Tentang Pencegahan Covid-19 Di Kelurahan Talikuran Utara Kecamatan Kawangkoan Utara. Kesmas. 2020;9(4):111-7.

19. Sujanto A. Psikologi Umum. Jakarta: Aksara Baru; 1986. 31 p.

20. Departemen Pendidikan Nasional. Kamus Besar Bahasa Indonesia (KBBI) pusat bahasa. cetakan pe. Jakarta: Gramedia Pustaka Utama; 2008. 1061 p.

21. Gibson D. Organisasi (Perilaku, Stuktur, Proses). Jilid 1, E. Jakarta: Binarupa Aksara; 1997.

22. Stephen P. Robbins dan Timothy A. Judge. Perilaku dan Manajemen Organisasi. Jakarta: Salemba Empat; 2016. $103 \mathrm{p}$.

23. Sunaryo. Psikologi Untuk
Keperawatan. Jakarta: Penerbit Buku Kedokteran EGCl; 2004.

24. Azizah N. Struktur dan Kultur Budaya dalam Keluarga di Era AKB (Adaptasi Kebiasaan Baru) di Lingkungan Keluarga Kota Bandung. Az-Zahra J Gend Fam Stud [Internet]. 2020;1(1):1-11. Available from: https://journal.uinsgd.ac.id/index.php/azza hra/article/view/9474

25. Azanella LA. Kuliah Tatap Muka Bisa Dimulai Juli 2021, Ini Penjelasan Ditjen Dikti [Internet]. Kompas.com. 2021. Available from: https://www.kompas.com/tren/read/2021/0 3/09/133802465/kuliah-tatap-muka-bisadimulai-juli-2021-ini-penjelasan-ditjendikti?page $=$ all

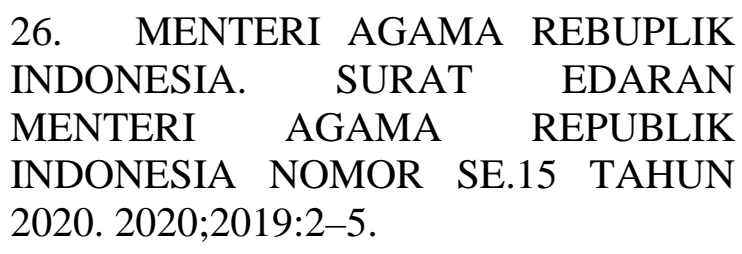

27. Segars J, Katler Q, McQueen DB, Kotlyar A, Glenn T, Knight Z, et al. Prior and novel coronaviruses, Coronavirus Disease 2019 (COVID-19), and human reproduction: what is known? Fertil Steril [Internet]. 2020;113(6):1140-9. Available from:

https://doi.org/10.1016/j.fertnstert.2020.04. 025

28. Mukharomah CF, Ahmad M, Pratama R, Sari MP. People's Knowledge and Behavior on the Covid-19 Virus Pandemic. La Geogr. 2021;19(2).

29. Trianto. Mendesain Model Pembelajaran Inovatif-Progresif. Jakarta: Kencana; 2011.

30. Prof.Dr.Sugiyono. Metode Penelitian Pendidikan. Bandung: Alfabeta; 2017. 290 p.

31. Tanzeh A. Metodologi Penelitian Praktis. 83 p. 
32. Prof.Dr.Sugiyono.

Metode

Penelitian Kualitatif. Edisi ke 3. Bandung:

Alfabeta CV; 2020. 181 p.

33. Prof.Dr.Sugiyono. Metode Penelitian Kuantitatif, Kualitatif dan R\&D. Bandung: Alfabeta; 2016. 2 p.

34. Notoatmojo PDS. Metodologi Penelitian Kesehatan. PT.Rineka Cipta; 2012.

35. Lathifa AR, Kamalia F, Putra FP, ... Student Compliance in Doing Health Protocols during the Covid-19 Pandemic. Proceding Inter ... [Internet]. 2021;1(1):18. Available from: https://press.umsida.ac.id/index.php/iiucp/a rticle/view/598

36. Alfonsius A. Pelayanan Transportasi Online Di Era New Normal. J Account Manag Innov [Internet]. 2020;4(2):91-100. Available from: https://ejournal.medan.uph.edu/index.php/j am/article/view/395

37. Simanjuntak DR, Napitupulu TM, Wele AM, Yanie R. Gambaran Kepatuhan Masyarakat Menerapkan Protokol Kesehatan COVID-19 Di Tempat Umum Periode September 2020 di DKI Jakarta. Fak Kedokt Univ Kristen Indones. 2020; (September 2020). 